\title{
Efficacy of mengkudu leaves extract (morinda citrifolia) on wound healing rate post tooth extraction in white rats (rattus norvegicus)
}

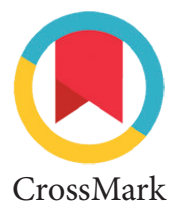

\author{
Muhammad I. Rasul*, Desy Setiady
}

\section{Abstract}

Objective: This study aims to determine the efficacy of mengkudu leaves extract to accelerate wound healing post tooth extraction in white rats. Material and Methods: Laboratory experimental study was carried out using post-test only and control group design. This study was measured by observing the duration of wound healing post tooth extraction, starting from the formation of sockets after tooth extraction until the socket closed, with sample of 27 white rats in three study groups in accordance with inclusion and exclusion criteria that have been determined.
Results: The average healing time in the negative control group is 19 days, the positive control group is 9 days, and the treatment group with mengkudu leaves extract is 7 days. Therefore, the fastest time of wound healing occurs in the treatment group, followed by the positive control group and lastly, in the negative control group.

Conclusion: Mengkudu leaves accelerate wound healing post tooth extraction in white male rats.
Department of Oral and Maxillofacial Surgery, Faculty of Dentistry, Hasanuddin University, Makassar, Indonesia
*Corresponding to:

Muhammad I. Rasul, Department of Oral and Maxillofacial Surgery, Faculty of Dentistry, Hasanuddin University, Makassar, Indonesia irfanrasul82@gmail.com

Received: 27 0ctober 2017 Revised: 16 November 2017 Accepted: 14 January 2018 Available online: 1 April 2018

Keywords: Tooth extraction, Wound healing, Mengkudu leaves, White rats

Cite this Article: Rasul MI, Setiady D. 2018. Efficacy of mengkudu leaves extract (morinda citrifolia) on wound healing rate post tooth extraction in white rats (rattus norvegicus). Journal of Dentomaxillofacial Science 3(1): 28-31. D0I: 10.15562/jdmfs.v3i1.547

\section{Introduction}

Tooth extraction is the most common procedure performed in oral surgery. After tooth extraction, a wound or opening, known as a socket, is formed. In some cases, wound healing does not proceed as it should, resulting in complications such as infection, pain, edema and hematoma. ${ }^{1-3}$

Wound healing is a natural process to restore the skin or mucosa to its normal form. The process consists of inflammatory, proliferation and remodeling phases. During the inflammatory phase, processes of vasoconstriction, hemostasis and inflammatory cell infiltration occur. The proliferative phase is evidenced by angiogenesis, collagen tissue deposition, granulation tissue formation, and epithelial cell migration. The remodeling phase is characterized by tissue and collagen remodeling, epidermal maturation and wound shrinkage. Generally, wounds are managed using the provision of irrigation, antibiotics, and antiseptics. Wound healing can be inhibited if the wound is not treated properly thus it can lead to complications..$^{4-9}$

Our ancestors have used herbal plants as medicine for centuries. The ancestors saw that plants used as food can also alleviate or cure disease. ${ }^{10,11}$

Mengkudu is a tropical plant found in Southeast Asia, the Pacific, South America and Central America. The genus name morindacitrifolia is derived from two Latin languages namely "morus", which means mulberry, and "indicus", which means
Indian, while cirtifolia indicates mengkudu plant leaves are similar to citrus species belonging to the Rubiaceae family. Mengkudu is known as noni in Hawaii, mulberry or nuna in India, and nhaut in South Asia. ${ }^{8-12}$

Mengkudu leaves compressed on wounds have been shown to lead to wound healing. The active ingredients found in mengkudu leaves are saponins, triterpens, tannins, alkaloids, iridoid glycosides, and flavonoids. The main effects of the chemical compounds contained in the mengkudu leaves associated with wound healing process including saponins as antibacterials, tannins as hemostatics, alkaloids as analgesics, and flavonoid compounds as antioxidants and anti-inflammatories. ${ }^{8}$ Mengkudu leaves extract improve the wound healing process and reduce healing time by binding to platelet-derived growth factor (PDGF) and adenosine (A2A) receptors that accelerate wound healing. ${ }^{7-12}$

The purpose of this study was to determine the efficacy of mengkudu leaves (morindacitrifolia) on wound healing post tooth extraction in white rats (rattusnorvegicus).

\section{Material and Methods}

This research was conducted at the Entomology Laboratory Faculty of Medicine, Hasanuddin University Makassar. Upon approval of the faculty's ethical committee, we took 27 male white rats 
(rattus norvegicus) in entomology laboratory from June 2016 to July 2016. The rats were divided into three study groups. Each group consisted of 9 rats, one negative control group (without treatment), one positive control group (povidone iodine) and one treatment group (mengkudu leaves extract). The type of research conducted is laboratory experimental research using post-test only with control group design.

Mengkudu leaves extracts were made in the laboratory using a maceration technique. The white rats were selected according to an inclusion criterion. The white rats were then placed in a cage, given food and drink three times daily and adapted for one week in a laboratory setting. Extraction of a single incisor was performed on each rat. In the treatment group, rats were treated with mengkudu leaves extract on the socket after tooth extraction. In the positive control group, rats were given povidone iodine, whereas in the negative control group, rats were not given any treatment. Clinical observations were performed on the 1st, 5 th, and 10th days of the treatment group and control groups by recording changes in depth, diameter and discoloration of the socket as well as swelling and bleeding occurring in the socket. The socket was evaluated daily until it closed.

Mean and standard deviation was calculated for each group and analyzed using ANOVA One Way test.

\section{Results}

Table 1 shows the average wound healing time post tooth extraction in the negative control group was $18.66 \pm 1.65$ days, in the positive control group was $8.88 \pm 1.16$ days and in treatment group was $7.11 \pm$ 1.05 days. This indicates that the fastest wound healing time post tooth extraction was found in group given mengkudu leaves extract, followed by the positive control group, and the longest healing time was in the negative control group.

Significant differences summarized in table 2 shows that: A. The mean wound healing time of the

Table 1 Distribution of mean and standard deviation of wound healing time post tooth extraction in each study group

\begin{tabular}{lcc}
\hline Group & $\begin{array}{c}\text { Mean of wound healing } \\
\text { time (Mean } \pm \text { SD) }\end{array}$ & Number of samples \\
\hline $\begin{array}{l}\text { Control (-) } \\
\text { (not given any treatment) }\end{array}$ & $18.66 \pm 1.65$ & 9 \\
$\begin{array}{l}\text { Control (+) } \\
\text { (PovidoneIodin) }\end{array}$ & $8.88 \pm 1.16$ & 9 \\
$\begin{array}{l}\text { Treatment } \\
\text { (Mengkudu leaves extract) }\end{array}$ & $7.11 \pm 1.05$ & 9 \\
\hline
\end{tabular}

negative control group was significantly different with than the positive control group and the treatment group. B. The mean time of wound healing of the positive control group was significantly different than the negative control group and the treatment group. C. The mean time of wound healing of the treatment group was significantly different than the negative control group and the positive control group.

Table 3 shows the mean of post tooth extraction socket depth on 1st day of the negative control group was $11.77 \mathrm{~mm}$, the positive control group was $11.88 \mathrm{~mm}$, and the treatment group was $11.88 \mathrm{~mm}$. The mean depth of the socket on 5 th day of the negative control group was $0 \mathrm{~mm}$, the positive control group was $0 \mathrm{~mm}$, and the treatment group was $0 \mathrm{~mm}$. The mean socket depth on 10th day of the negative control group was $0 \mathrm{~mm}$, the positive control group was $0 \mathrm{~mm}$, the treatment group was $0 \mathrm{~mm}$.

Table 4 shows the mean of socket diameter after tooth extraction on 1st day of the negative control group was $4.67 \mathrm{~mm}$, the positive control group was $4.44 \mathrm{~mm}$, and treatment group was $4.78 \mathrm{~mm}$. The mean socket diameter on 5th day of the negative control group was $3 \mathrm{~mm}$, the positive control group was $1 \mathrm{~mm}$, and the treatment group was $0.33 \mathrm{~mm}$. The mean socket diameter on 10th day of the negative control group was $1 \mathrm{~mm}$, the positive control group was $0 \mathrm{~mm}$, and the treatment group was $0 \mathrm{~mm}$. This indicates that the diameter of the tooth socket closes most rapidly in the group given mengkudu leaves extract, followed by the positive control group and lastly the negative control group. Mean of socket diameter after extraction on the 1st day of the negative control group was $4.67 \mathrm{~mm}$, the positive control group was $4.44 \mathrm{~mm}$, and the treatment group was $4.78 \mathrm{~mm}$. The mean socket diameter on the 5th day of the negative control group was $3 \mathrm{~mm}$, the positive control group was $1 \mathrm{~mm}$, and treatment group was $0.33 \mathrm{~mm}$. The mean socket diameter on the 10th day of the negative control group was $1 \mathrm{~mm}$, the positive control group was $0 \mathrm{~mm}$ and the treatment group was $0 \mathrm{~mm}$. In the negative control group, there was change in socket diameter of $1.67 \mathrm{~mm}$ between the 1st and 5th day, while on 5th and 10th day, the difference of socket diameter was $2 \mathrm{~mm}$. In the positive control group, difference in socket diameter was $3.44 \mathrm{~mm}$ between the 1 st and 5 th day, while by the 10th day the socket was closed. In the treatment group, the difference in socket diameter was $4.45 \mathrm{~mm}$ between the 1st and 5 th day, while on the 10th day the socket was also closed.

Table 5 shows the results of clinical observations on 1st, 5 th, 10th days by observing mucosal changes, presence or absence of swelling, and 
Table 2 Analysis of Least Significant Difference test of wound healing time after tooth extraction inter-groups

\begin{tabular}{lccc}
\hline Groups & Comparison & Mean difference & Sig \\
\hline Control (-) & Control (+) & $9.77778^{*}$ & .000 \\
Without any treatment & Treatment & $11.55556^{*}$ & .000 \\
Control (+) & Control (-) & $-9.77778^{*}$ & .000 \\
Povidone Iodine & Treatment & $1.77778^{*}$ & .009 \\
Treatment Mengkudu & Control (-) & $-11.55556^{*}$ & .000 \\
leaves extract & Control (+) & $-1.77778^{*}$ & .009 \\
\hline
\end{tabular}

Table 3 Changes in socket depths in each study group

\begin{tabular}{lccc}
\hline \multirow{2}{*}{ Study objects } & \multicolumn{3}{c}{ Mean of socket depth $(\mathbf{m m})$} \\
\cline { 2 - 4 } & 1st Day & 5th Day & 10th Day \\
\hline $\begin{array}{l}\text { Control (-) } \\
\text { (Without Treatment) }\end{array}$ & $11.77 \mathrm{~mm}$ & $0 \mathrm{~mm}$ & $0 \mathrm{~mm}$ \\
$\begin{array}{l}\text { Control (+) } \\
\text { (Povidone Iodine) }\end{array}$ & $11.88 \mathrm{~mm}$ & $0 \mathrm{~mm}$ & $0 \mathrm{~mm}$ \\
$\begin{array}{l}\text { Treatment (Mengkudu } \\
\text { leaves extract) }\end{array}$ & $11.88 \mathrm{~mm}$ & $0 \mathrm{~mm}$ & $0 \mathrm{~mm}$ \\
\hline
\end{tabular}

Table 4 Changes in socket diameter in each study group

\begin{tabular}{lccc}
\hline \multirow{2}{*}{ Study objects } & \multicolumn{3}{c}{ Mean of socket depth (mm) } \\
\cline { 2 - 4 } & 1st Day & 5th Day & 10th Day \\
\hline $\begin{array}{l}\text { Control (-) } \\
\text { (Without Treatment) }\end{array}$ & $4.67 \mathrm{~mm}$ & $3 \mathrm{~mm}$ & $1 \mathrm{~mm}$ \\
$\begin{array}{l}\text { Control (+) } \\
\text { (Povidone Iodine) }\end{array}$ & $4.44 \mathrm{~mm}$ & $1 \mathrm{~mm}$ & $0 \mathrm{~mm}$ \\
$\begin{array}{l}\text { Treatment (Mengkudu } \\
\text { leaves extract) }\end{array}$ & $4.78 \mathrm{~mm}$ & $0.33 \mathrm{~mm}$ & $0 \mathrm{~mm}$ \\
\hline
\end{tabular}

Table 5 Clinical observation of bleeding, edema, and discoloration of socket post tooth extraction on 1st, 5 th and 10th day

\begin{tabular}{|c|c|c|c|c|c|c|c|c|c|}
\hline \multirow{2}{*}{ Study objects } & \multicolumn{3}{|c|}{ 1st Day } & \multicolumn{3}{|c|}{ 5th Day } & \multicolumn{3}{|c|}{ 10th Day } \\
\hline & P1 & P2 & P3 & P1 & P2 & P3 & P1 & P2 & P3 \\
\hline $\begin{array}{l}\text { Control (-) } \\
\text { ( Without } \\
\text { Treatment ) }\end{array}$ & $\mathrm{O}$ & $\mathrm{O}$ & $\mathrm{O}$ & $\mathrm{X}$ & $\mathrm{O}$ & $\mathrm{O}$ & $\mathrm{X}$ & $\mathrm{X}$ & $\mathrm{O}$ \\
\hline $\begin{array}{l}\text { Control (+) } \\
\text { (Povidone Iodine) }\end{array}$ & $\mathrm{O}$ & $\mathrm{O}$ & $\mathrm{O}$ & $\mathrm{X}$ & $\mathrm{X}$ & $\mathrm{O}$ & $\mathrm{X}$ & $\mathrm{X}$ & $\mathrm{O}$ \\
\hline $\begin{array}{l}\text { Treatment } \\
\text { (Mengkudu } \\
\text { leaves extract) }\end{array}$ & $\mathrm{O}$ & $\mathrm{O}$ & $\mathrm{O}$ & $\mathrm{X}$ & $\mathrm{X}$ & $\mathrm{X}$ & $\mathrm{X}$ & $\mathrm{X}$ & $\mathrm{X}$ \\
\hline
\end{tabular}

${ }^{*}$ Notes: $\mathrm{P} 1=$ Bleeding

$\mathrm{O}=$ Present

$\mathrm{P} 2=$ Edema

$\mathrm{X}=$ Absence

P3 $=$ Discoloration bleeding. Observations on the first day show mucosa became reddish and swelling and bleeding occured in the negative control group, the positive control group and the treatment group. This is due to the tooth extraction procedure breaking blood vessels. On 5th day, the negative control group had no visible bleeding while swelling was visible and the mucosa appeared more red. In the positive control group, bleeding and swelling were absent while the mucosa appeared more red. The treatment group mucosa appeared almost cured and no evidence of swelling or bleeding. On 10th day, the negative control group had no evidence of bleeding and swelling while the mucosa color was slightly redder than the normal mucosa, whereas in the positive control group and treatment group observed complete wound closure.

\section{Discussion}

White rats were the ideal choice as they have many advantages, most importantly their good adaptation and healing tissue that resembles humans. The selection of the male sex was due to its more stable biological condition compared to female rats whose biological conditions were affected by the estrous cycle. In addition to uniformity of sex, weight and age of rats were also uniformed to minimize biological variability between experimental animals. This is expected to provide a relatively uniform response to the treatments used in this study. The grouping of animals was selected randomly so that rats in each group had equal opportunity to be used as a research sample.

The distribution of differences in the duration of wound healing post tooth extraction in each study group was monitored. In negative control group, on average, it took about 19 days to heal. In the positive control group given providine iodine, on average, it took 9 days to heal. In the treatment group given mengkudu leaves extract, on average, it took 7 days to heal. There was an average 10-day healing time difference between the negative control group and positive control, 2 days on positive control and treatment group, and 12 days in the negative group and the treatment group. The mean depth of the post tooth extraction socket on the 1 st day in the negative control group was $11.77 \mathrm{~mm}$, the positive control group was $11.88 \mathrm{~mm}$, the treatment group was $11.88 \mathrm{~mm}$. The mean depth of the socket on the 5 th day in the negative control group was $0 \mathrm{~mm}$, the positive control group was $0 \mathrm{~mm}$ and 
treatment group was $0 \mathrm{~mm}$. The mean depth of the socket on the 10th day in the negative control group was $0 \mathrm{~mm}$, the positive control group was $0 \mathrm{~mm}$ and treatment group was $0 \mathrm{~mm}$.

In the wound healing process, tannins are known to have anti-bleeding and anti-inflammatory effects. The tannin compound is an astringent compound that has a bitter taste due to its polyphenol group that can bind, precipitate or shrink proteins. One of the most important properties of tannins and tannic acids is its ability to form chelate complexes with metal ions. Tannin acid can also serve as a natural antimicrobial agent. Flavonoids found in mengkudu leaves are phenolic compounds widely found in plant tissue and act as anti-oxidants. The anti-oxidative activity of flavonoids originates from its ability to donate a hydrogen atom or through its ability to chelate metals. In addition to its anti-oxidant effect, flavonoids have the ability to inhibit other biological effects because they have anti-viral, anti-cancer, anti-bacterial, anti-fungal, anti-inflammatory and anti-ischemic properties. Flavanoids also act as vasodilators. In wound healing, saponins are integral to stop bleeding because they accelerate precipitation and coagulation of red blood cells. In addition to being anti-inflammatory saponins are also known to accelerate the formation of new blood vessels (angiogenesis) during the wound healing process. ${ }^{13-19}$

Their studies described the wound healing occurred more quickly in subjects given $10 \%$ topical mengkudu leaves ethanol extract compared with subjects given $10 \%$ povidone iodine as a control. ${ }^{16}$

\section{Conclusion}

There was a significant difference in wound healing time between the treatment group and the control group. The group treated using mengkudu leaves extract (morindacitrifolia) post tooth extraction of white male rats recovered faster than the group not given mengkudu leaves extract. In other words, application of mengkudu (morinda citrifolia) results in accelerated and effective wound healing post tooth extraction.

\section{Acknowledgement}

The author state no funding to declare.

\section{Conflict of Interest}

The authors report no conflict of interest.

\section{References}

1. Oroh CG, Damajanty HC, Christy NM. Efektivitas lender bekicot (achatinafulica) terhadap jumlah sel fibroblast pada luka pasca pencabutan gigi tikus wistar. Jurnal e-Gigi 2015;3: 516.

2. Adeyemo WL, Akinola LL, Mobolanie OO. Clinical evaluation of post-extraction site wound healing. J Contemp Dent Pract 2006;7: 40-49.

3. Fragiskos FD. Peroperatif and postoperative complication. In Oral surgery. New York: Springer; 2007. p. 181

4. Zulfa, Elly N, Dewi G. Perbandingan penyembuhan luka terbuka menggunakan balutan madu atau balutan normal saline-povidone iodine. Jurnal Keperawatan Indonesia 2008; 12: 34-39.

5. Suwiti NK. Deteksi histologic kesembuhan luka pada kulit pasca pemberian daun mengkudu (Morindacitrofilialinn). Buletin Veteriner Udayana 2010;2: 1-8.

6. Daniel L. The development of anesthesiology in oral and maxillofacial surgery. Oral Maxillofac Surg Clin North Am 2013:25: 341-355.

7. Sabirin IP, Ani MM, Bethy SH. Peran ekstrak etanol topical daun mengkudu (morindacitrifolia 1.) pada penyembuhan luka ditinjau dari imunoekspresi CD34 dan kolagen pada tikus galur wistar. MKB 2013;45: 226-232.

8. Yuslianti ER, Rahmayani LP, Afifah BS. Effectiveness of noni (morindacitrifolia 1.) leave extract gel as standardized traditional medicine to accelerate oral mucosa wound healing on wistar rats. J Medical Plant 2014;8: 156-160.

9. Tamales D, Dewi N, Rosida L. Extract of haruan (channa striata) extract increasing reepithelialisation count in wound healing process on wistar rat's buccal mucosa. J Dentomaxillofac Sci 2016;1: 12-15.

10. Rasal Vp, Arulmozhi S, Purnima A, et al. Wound healing and antioxidant activities of morinda citrifolia leaf extract in rats. J Pharmacol Ther 2007;7: 49-52.

11. Yogesh S, Jeyabalan G, Ramandeep S, et al. Current aspects of wound healing agents from medicinal plants: a review. J Med Plants Stud 2013;1: 1-11.

12. Assi RA, Yusrida D, Ibahim MA, et al. Morindacitrifolia (noni): a comprehensive review in its industrial uses, pharmacological activities and clinical trials. Arab J Chem 2017;10: 691-707.

13. Güclü-Ustündağ O, Mazza G. Saponins: properties, applications and processing. Crit Rev Food Sci Nutr 2007;47: 231-258.

14. Ismarani. Potensi senyawa tannin dalam menunjang produksi ramah lingkungan. CEFARS 2012;3: 46-55.

15. Prochazkova D, Bousova I, Wilhelmova N. Antioxidant and prooxidant properties of flavonoids. Fitoterapia 2011;82: 513-523.

16. Yuslianti ER, Sabirin IPR, Sovia E. Effect of topical ethanol extracts of morindacitrofilia L. leaves on excisional wound healing. Int J Pharmacol 2013;9: 318-321.

17. Brunetty C, Ferdinando M, Aliissio F, et al. Flavonoids as antioxidants and developmental regulators: relative significance in plants and humans. Int J Mol Sci 2013;14: 3540-3555.

18. Agati G, Azzarello, Pollastri S, et al. Flavonoids as antioxidants in plants: location and functional significance. Plant Sci J 2012;196: 67-76.

19. HernándezI, Alegre L, Van-Breusegem F, et al. How relevant are flavonoids as antioxidants in plants. Trends Plant Sci 2009;14: 125-132.

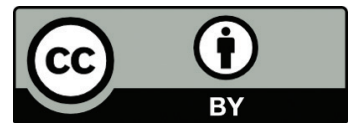

This work is licensed under a Creative Commons Attribution 